\section{PYURIA AND BACILLURIA IN CHILDREN}

\section{BY}

\section{J. N. CUMINGS, M.B., M.R.C.P.}

(From the Children's Department, King's College Hospital)

This paper consists of two parts, both of which deal primarily with normal children, but some remarks have been added concerning abnormal cases in which the methods developed for investigating the former have been employed.

Cuthbert Dukes ${ }^{1}$ has described a method of counting pus cells in urine by which a definite comparison can be made between specimens from several children or between consecutive specimens from one child. He also defines " pyuria," limiting the term in adults to those cases which show more than 100 pus cells per c.mm. He regards figures between 10 and 100 per c.mm. in adults as indicating "excess of leucocytes" and figures below 10 per c.mm. as being within normal limits. ${ }^{2}$ He describes a urine as containing so many pus cells per c.mm. instead of so many cells per field of a microscope. There can be no doubt that this method, although it involves a little more trouble, is more accurate. It could be adopted especially in hospitals, and would not be very difficult to carry out in' general practice. The method employed in this investigation is a slight modification of that of Cuthbert Dukes, and will first be described.

\section{Method of Counting Pus Cells in Urine}

When a fresh specimen of urine has been collected and well mixed, a drop is placed with a pipette on an ordinary counting chamber, such as is used in making a red or white blood corpuscle count. The counting of the pus cells is done as in a white blood corpuscle count, the total number being enumerated in $1 / 2$ or $1 \mathrm{c} . \mathrm{cm}$. In a female child : with a vaginal discharge thorough washing must first be carried out around the vulva and urethral orifice with a lotion such as boric acid or normal saline, only the second portion of the specimen being retained.

\section{Results of Investigation}

A series of eighty-eight boys was examined, all of whom could be considered as normal, their ages ranging from 7 weeks to 12 years. Of these, eighty-five had no pus cells per c.mm. The other three had 2, 4, and 2 pus cells per c.mm., their ages being 8,6 , and 12 years respectively. Only 3.4 per cent: of healthy boys, therefore, had even the slightest abnormality in the nature of pus cells in their urine.

A series of eighty girls was taken, all of whom appeared to be normal, with ages ranging from $8 \frac{1}{2}$ months to 11 years. Of these, thirty-six had no pus cells per c.mm.that is, $\mathbf{5 5}$ per cent. of the girls had a certain number of pus cells present in their urine. The highest count was obtained in a girl, aged 10 years, who had 64 per c.mm. ; the next highest was 44 ; then followed 28,24 , and 22 . There were seven between 10 and 22, twelve between 5 and 10, and twenty between 0 and 5 . None of these children had any urinary symptoms or vaginal discharge, nor would any of the cases fall within Cuthbert Dukes's definition of " pyuria," but twelve would be classed among the "excess of leucocytes" group, and therefore would be presumably abnormal.

The above figurés give some data on which to consider abnormal cases, such as those of children suffering from pyelitis and cystitis.

\section{Cystitis}

The details of the following three cases of cystitis show the gradual reduction in the number of pus cells in the urine. Each table indicates the method of treatment and whether the urine was clear or opalescent.

Cystitis, Female, aged 10 years

\begin{tabular}{|c|c|c|c|}
\hline Date & $\begin{array}{l}\text { No. of Cells } \\
\text { per c.mm. }\end{array}$ & $\underset{\text { Urine }}{\text { Character of }}$ & Treatment Adopted \\
\hline 1929 & & & \\
\hline Dec. 31 & 3,560 & Opalescent & Pot. cit:, gr. 200 per diem \\
\hline 1930 & & & \\
\hline Jan. 1 & 2,776 & Opalescent & \\
\hline Jan. 8 & 948 & Opalescent & \\
\hline Jan. 10 & $18, c 00$ & Opalescent & Jan. 9th. Hexamine, gr. 20 \\
\hline Jan. 11 & 268 & Very slightly & per diem \\
\hline Jan. 20 & 160 & $\begin{array}{l}\text { opalescent } \\
\text { Not opalescent, but }\end{array}$ & - \\
\hline Feb. 1 & 10 & $\begin{array}{c}\text { not quite clear } \\
\text { Clear }\end{array}$ & \\
\hline March 3 & 2 & Clear & \\
\hline
\end{tabular}

Cy'stitis, Female, aged 8 years

\begin{tabular}{c|c|c|c}
\hline Date & $\begin{array}{c}\text { No. of Cells } \\
\text { per c.mm. }\end{array}$ & $\begin{array}{c}\text { Character of } \\
\text { Urine }\end{array}$ & Treatment Adopted \\
\hline 1930 & 7,000 & Opalescent & Pot. cit., gr. 80 per diem \\
Jan. 21 & 700 & $\begin{array}{c}\text { Opalescent } \\
\text { Opalescent } \\
\text { Feb. 1 }\end{array}$ & $\begin{array}{l}\text { Jan. 24th. Hexamine gr. 20 } \\
\text { per diem } \\
\text { Feb. 5th. Pot. cit., gr. 120 } \\
\text { per diem } \\
\text { Feb. 10th. Pot. cit., gr. 160 } \\
\text { per diem } \\
\text { Feb. 5 }\end{array}$ Fear \\
Feb. 14 & 28 & Clear & \\
\hline
\end{tabular}

Cystitis, Female, aged 2 years

\begin{tabular}{|c|c|c|c|}
\hline Date & $\begin{array}{l}\text { No. of Cells } \\
\text { per c. } \mathrm{mm} \text {. }\end{array}$ & $\underset{\text { Crine }}{\text { Character of }}$ & Treatment Adopted \\
\hline 1930 & & & \\
\hline April ${ }^{16}$ & 6,200 & Opalescent & April 17th. Hexamine \\
\hline April 27 & $\therefore \quad 600$ & Opalescent & gr.o per diem \\
\hline May 7 & 62 & Clear & \\
\hline May 20 & 8 & Clear & . \\
\hline
\end{tabular}

The object in giving the above tables in full is to demonstrate the value of an accurate count, and to indicate how much easier it is to follow the progress of the case by this method.

\section{Pyelitis}

Of three patients with pyelitis, one was a male infant aged 6 months, another a boy aged 10 months; the third was a girl aged 2 years. The first two cases have been very resistant to treatment, the number of pus cells having fluctuated from 300 up to 40,000 per c.mm. in both cases, with an average figure of about 2,000. The third case is recorded in the form of a table to show the effect of treatment, which was successful, as the figures indicate.

Pyclitis, Female, aged 2 years

\begin{tabular}{c|c|c|c}
\hline Date & $\begin{array}{c}\text { No. of Cells } \\
\text { per c.mm. }\end{array}$ & $\begin{array}{c}\text { Character of } \\
\text { Urine }\end{array}$ & Treatment Adopted \\
\hline Feb. 17 & 3,240 & Opalescent & Feb. 17th. Pot. cit., gr. 96 \\
Feb. 19 & 4,000 & Opalescent & per diem \\
Feb. 22 & 450 & Less opalescent & \\
Feb. 26 & 14 & Clear & \\
March 9 & 14 & Clear & \\
March 13 & 36 & Clear & \\
March 23 & 0 & Clear & \\
\hline
\end{tabular}




\section{Pus Cell Count in Other Conditions}

A few additional cases of interest will now be mentioned. The first is that of a boy, aged 15 months, who had a septic sore on his foreskin, yet the number of pus cells per c.mm. was only 4. In a girl aged 10 years, suffering from haemorrhagic nephritis, there were 24 pus cells and 300 red blood corpuscles per c.mm. A boy, aged 7 years, with acute nephritis had 10 pus cells and 84 red blood corpuscles per c.mm. Another girl, aged $9 \frac{1}{2}$ years, who had just had scarlet fever, was found to have 282 (and on a second occasion 290) pus cells and 16 red blood corpuscles per c.mm. The last case in this series is that of a girl, aged 10 years, who had a vaginal discharge. The urine showed 192 pus cells per c.mm. on the first examination; twelve days later there were 500, but after efficient treatment for eight days the number was only 44 -too low for Cuthbert Dukes's definition of "pyuria," but within his figures for " excess of leucocytes."

\section{Numerical Definition of "Pyuria"}

The question what figure should be considered to constitute " pyuria," and what figure separates normal from abnormal, is of considerable interest. From the above observations it is suggested that in boys figures of over 10 per c.mm., and in girls over 100 per c.mm., should be regarded as abnormal and of pathological significancethat is, "pyuria." The term " excess of leucocytes" would seem to be superfluous.

\section{Necessity for Microscopical Examination}

Another point is whether urine containing the low pathological figures can be recognized with the naked eye, and at what figure definite opalescence occurs. From the above investigations it was seen that figures over 200 per c.mm. represented just opalescent urine, while below that figure the urine was clear. It is a fallacy, therefore, to say that pyuria can be recognized by naked-eye examination of the urine; it requires a microscopical examination to settle this important point

\section{Bacilluria in Normal Children}

A series of forty normal children was taken. Two specimens of urine were collected from each child, one in the ordinary manner, the other being obtained by collecting the urine in sterile test tubes after the penis or the vulva had been cleaned with boric acid lotion followed by sterile normal saline. The latter, is referred to as the " clean" specimen. Cultures were put up on agar from both specimens, and incubated for twenty-four hours. The nature of the growth, if any, was then investigated, and the results classified in three groups.

Group 1 consisted of those children whose urine was sterile both in the clean and in the ordinary specimens. There were nineteen in this section-thirteen boys and six girls.

Group 2 consisted of fifteen children-five boys and ten girls. The clean specimens were sterile, but the ordinary specimens were contaminated. No organisms, therefore, were present in the urine of. the children in this group. Organisms in the ordinary specimens must have been due to external contamination.

Group 3 consisted of four girls and two baby boys. In all $B$. coli were grown from both specimens.

In 90 per cent. of the twenty boys the clean specimens were sterile; if the infants are excluded-and it is very problematic whether it is possible to exclude contamination in these-100 per cent. had no organisms in their urine. The urine was sterile in 80 per cent. of the twenty girls.

Careful study of the three groups reveals that the proportion of girls to boys in each increases from Grovp 1 to Group 3, and that only in six girls were the ordinary

specimens not contaminated. This seems to be strong evidence that in the remaining 20 per cent. organisms were present in the clean specimens owing to some external contamination, and that it is much more difficult to obtain a clean specimen from a female child than from a male child. The fact that there were no boys (excluding infants) from Group 3 also favours this view. One may conclude that the presence of organisms in the urine of a child is abnormal, though it does not necessarily indicate a pathological lesion of the urinary tract.

\section{Summary}

1. The presence of leucocytes in the urine of normal children does occur; in boys as many as 10 per c.mm. can be considered as being within normal limits; in girls as many as 100 per c.mm. (the urine having been collected without any precautions). Figures exceeding these should be regarded as having pathological significance.

2. The enumeration of pus cells by the method described above might be more widely adopted, as it forms an accurate means of following the progress of a: case from day to day and of comparing one case with another.

3. Bacilluria does not occur in normal children.

My thanks are due to Professor Still for permission to publish particulars about some of these cases, and to Dr. W. P. H. Sheldon for his untiring help throughout these investigations.

${ }^{1}$ Dukes, C.: British Medical Journal, 1928, i, 391.

2 Idem: Proc. Roy. Soc. Med., Section of Pathology, March 20th, 1928.

\section{THERAPEUTIC EVALUATION IN THE TREATMENT OF SYPHILIS \\ BY}

E. TYTLER BURKE, D.S.O., M.B., СH.B. DIRECTOR OF MUNICIPAL CLINIC (V.D.), SALFORD

In estimating the amount of treatment which can be considered adequate for any case of syphilis, at least three elements must be taken into consideration: (1) the nature of the agents used; (2) the dosage given; and (3) the period over which they have been administered.

One syphilologist may find that in primary seronegative syphilis cure can only be brought about by the administration; during a period of thirty-six weeks, of 12.6 grams of an arsenobenzene compound (Ab. C.) plus that of a bismuth preparation in which the metal content amounts to 7.2 grams. Another may claim that by adopting a different principle of treatment, and by using either the same or different agents, cure can be attained in twentysix weeks by giving 10.35 grams of $\mathrm{Ab}$. C. together with a bismuth preparation in which the total quantity of the element amounts to 1.28 grams. It is not necessary to consider here which of the two methods is correct, or if one is more accurate than the other. What it is desired to point out is that the mode of assessing the amount of therapy administered is unsound, and does not present a true picture of the position.

\section{Dosage}

The first point to observe is that the $\mathrm{Ab}$. C. dosage is expressed in terms of the actual compound itself (not of the arsenic), whereas that of the bismuth takes cognizance only of the elemental content. Now the therapeutio potency of an arsenical agent in the treatment of syphilis does not vary directly with its arsenic content. Various compounds contain various amounts of the element, from 18 to 22 per cent. or more. The pentavalent arsenicals such as stovarsol and tryparsamide are of lower therapeutic value than the trivalents; although their respective arsenic contents are 27 and 25 per cent. The dosage of $\mathrm{Ab}$. C. is regulated not by the amount of arsenic present, 